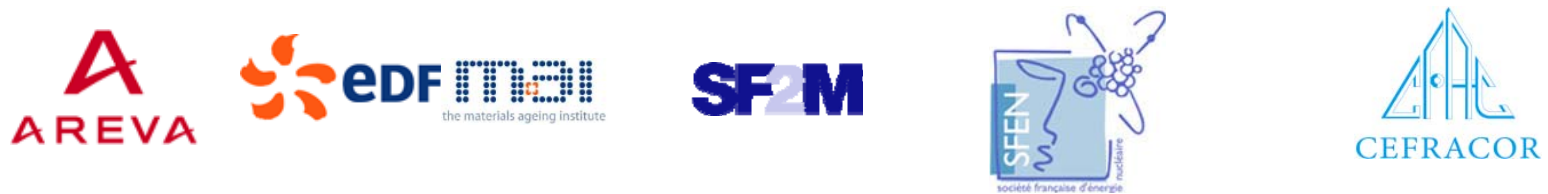

\section{MIN口S}

Centre of Excellence for Nuclear Materials

\section{Workshop}

Materials Innovation for Nuclear Optimized Systems
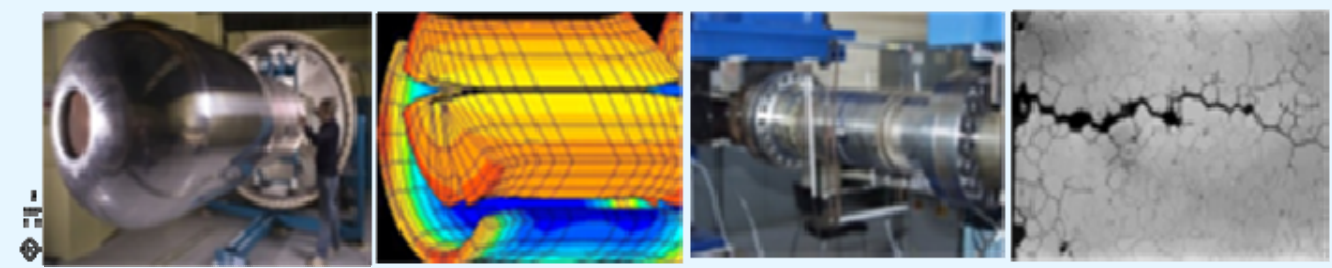

December 5-7, 2012, CEA - INSTN Saclay, France

\section{Catherine GUERRE et al.}

CEA (France)

Stress Corrosion Cracking of Nickel Base Alloys in PWR Primary Water

Workshop organized by:

Christophe GALLÉ, CEA/MINOS, Saclay - christophe.galle@cea.fr Constantin MEIS, CEA/INSTN, Saclay - constantin.meis@cea.fr 


\title{
Stress Corrosion Cracking of Nickel Base Alloys in PWR Primary Water
}

\author{
Catherine GUERRE ${ }^{1}$, Elizabeth CHAUMUN $^{1}$, Jérôme CRÉPIN ${ }^{2}$, lan de CURIÈRES ${ }^{3}$, \\ Cécilie DUHAMEL ${ }^{2}$, Eva HÉRIPRÉ ${ }^{4}$, Emmanuel HERMS ${ }^{1}$, Pierre LAGHOUTARIS $^{1}$, \\ Régine MOLINS ${ }^{2}$, Mohamed SENNOUR ${ }^{2}$, François VAILLANT ${ }^{5}$ \\ ${ }^{1}$ CEA-DEN-DPC, Service de la Corrosion et du Comportement des Matériaux dans leur Environnement, SCCME (Saclay, France) \\ ${ }^{2}$ MINES Paristech, Centre des matériaux, CNRS UMR 7633 (Evry, France) \\ ${ }^{3}$ Institute for Radiological Protection and Nuclear Safety (IRSN), DSR/SAMS (Fontenay-aux-Roses,France) \\ ${ }^{4}$ Laboratoire de Mécanique des Solides, Ecole Polytechnique (Palaiseau, France) \\ ${ }^{5}$ EDF R\&D - MMC (Moret-sur-Loing, France)
}

Stress corrosion cracking (SCC) of nickel base alloys and associated weld metals in primary water is one of the major concerns for pressurized water reactors (PWR). Since the 90's, highly cold-worked stainless steels (non-sensitized) were also found to be susceptible to SCC in PWR primary water ([1], [2], [3]). In the context of the life extension of pressurized water reactors, laboratory studies are performed in order to evaluate the SCC behaviour of components made of nickel base alloys and of stainless steels. Some exemples of these laboratory studies performed at CEA will be given in the talk. This presentation deals with both initiation and propagation of stress corrosion cracks.

The aims of these studies is, on one hand, to obtain more data regarding initiation time or crack growth rate and, one the other hand, to improve our knowledge of the SCC mechanisms. The aim of these approaches is to model SCC and to predict components life duration. Crack growth rate (CGR) tests on Alloy 82 with and without post weld heat treatment are performed in PWR primary water (Figure 1). The heat treatment seems to be highly beneficial by decreasing the CGR. This result could be explai-ned by the effect of thermal treatment on the grain boundary nanoscopic precipitation in Alloy 82 [4].

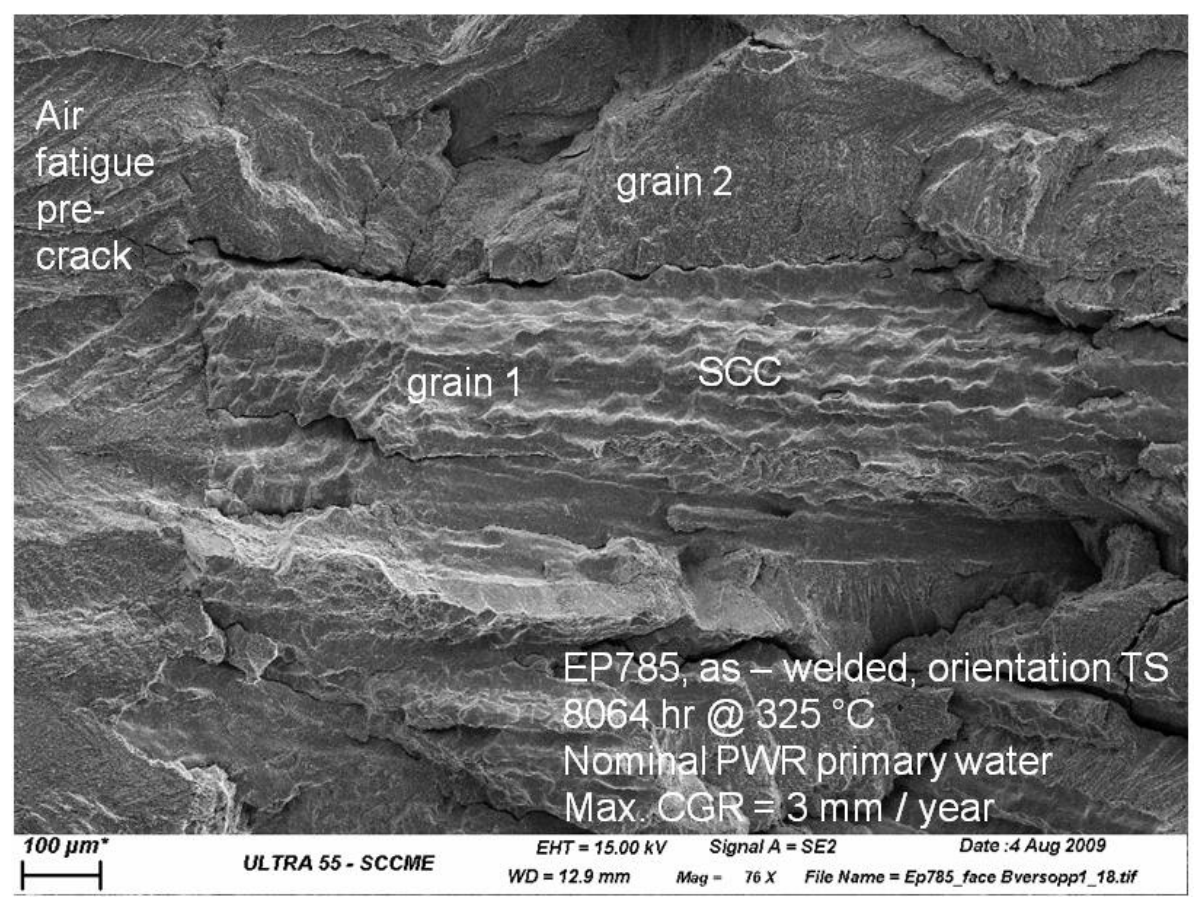

Fig. 1: Fracture surface of an Alloy $82 \mathrm{CT}$ specimen tested $8064 \mathrm{hr}$ at $325^{\circ} \mathrm{C}$ in simulated PWR primary water, view of an isolated intergranular SCC crack (Scanning Electron Microscopy). 
The susceptibility to SCC of cold worked austenitic stainless steels is also studied. It is shown that for a given cold-working procedure, SCC susceptibility increases with increasing cold-work ([2], [5]). Despite the fact that the SCC behaviour of Alloy 600 has been widely studied for many years, recent laboratory experiments and analysis ([6], [7], [8]) showed that oxygen diffusion is not a rate-limiting step in the SCC mechanism and that chromium diffusion in the bulk close the crack tip could be a key parameter.

\section{References}

[1] T. Couvant, P. Moulart, L. Legras, P. Bordes, J. Capelle, Y. Rouillon, T. Balon, PWSCC of austenitic stainless steels of heaters of pressurizers, Proceedings of the Fontevraud $\mathrm{V}$ international symposium, Contribution of materials investigation to the resolution of problems encountered in pressurized water reactors, 23-27 september 2002.

[2] D. Feron, E. Herms, B. Tanguy, Behavior of stainless steels in pressurized water reactor primary circuits, Journal of Nuclear Materials, 2012, 427 (1-3) , pp. 364-377.

[3] C. Guerre, E. Herms, O. Raquet, S. Marie, M. Le Calvar, SCC crack growth rate of cold work austenitic stainless steels in PWR primary water conditions, 13th International Conference on Environmental Degradation in Nuclear Power Systems, Whistler, British Columbia, August 19 - 23, 2007

[4] C. Guerre, C. Duhamel, M. Sennour, J. Crépin, M. Le Calvar, SCC crack growth rate of Alloy 82 in PWR primary water conditions - effect of a thermal treatment, $15^{\text {th }}$ International Conference on Environmental Degradation of Materials in Nuclear Power Systems-Water Reactors, Colorado Springs, Colorado, August 7 - 11, 2011.

[5] E. Herms, O. Raquet, L. Séjourné, F. Vaillant, SCC of Cold-Worked Austenitic Stainless Steels Exposed to PWR Primary Water Conditions : Susceptibility to Initiation, EUROCORR 2009 septembre 2009, Nice (France), paper 7861.

[6] M. Sennour, P. Laghoutaris, C. Guerre, R. Molins, Advanced TEM characterization of stress corrosion cracking of Alloy 600 in pressurized water reactor primary water environment, Journal of Nuclear Materials 393 (2009) 254-266.

[7] C. Guerre, P. Laghoutaris, J. Chêne, L. Marchetti, R. Molins, C. Duhamel, M. Sennour, Stress corrosion cracking of Alloy 600 in PWR primary water : influence of chromium, hydrogen and oxygen diffusion, $15^{\text {th }}$ International Conference on Environmental Degradation of Materials in Nuclear Power Systems-Water Reactors, Colorado Springs, Colorado, August 7 - 11, 2011.

[8] P. Laghoutaris, C. Guerre, J. Chene, R. Molins, F. Vaillant, I. De Curieres, Contribution to model stress corrosion cracking of Alloy 600 in PWR primary water, Workshop on Detection, Avoidance, Mechanisms, Modeling, and Prediction of SCC Initiation in Water-Cooled Nuclear Reactor Plants, 07/09/2008 - 12/09/2008, Beaune, France. 
DE LA RECHERCHE À L'INDUSTRIE

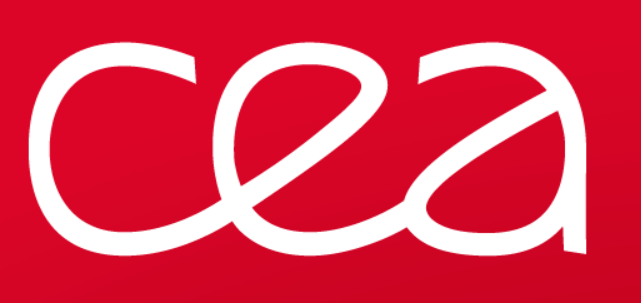

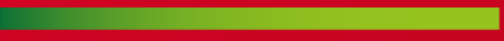

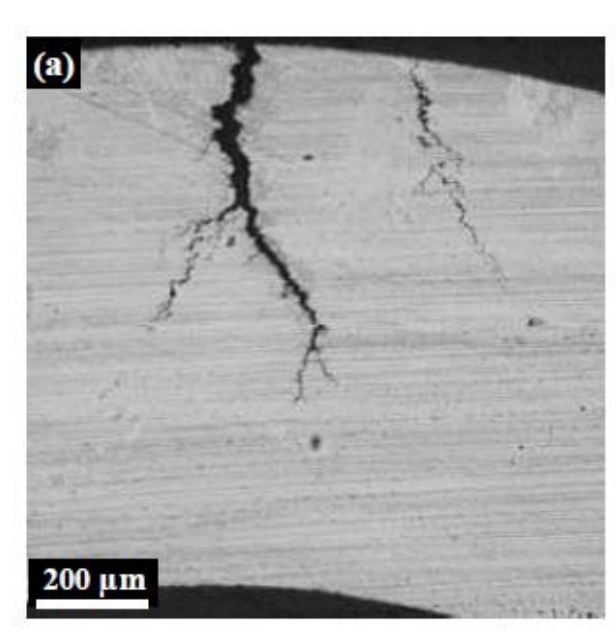

Alloy 600 , heat NX2650

U-bend specimen

$1538 \mathrm{hr}$ in nominal PWR primary water at $330^{\circ} \mathrm{C}$

\section{Stress corrosion cracking of nickel base alloys in PWR primary water}

C. Guerre, CEA Saclay

E. Chaumun, E. Herms, P. Laghoutaris, CEA Saclay

J. Crépin, C. Duhamel, R. Molins, M. Sennour, Mines Paristech E. Héripré, LMS, Ecole Polytechnique

F. Vaillant, EDF R\&D

I. de Curières, IRSN 


\section{CONTEXT : SCC}

\section{MINDS}

\section{Stress Corrosion Cracking (SCC)}

- Cracking of a material induced from the combined influence of a tensile stress and a environment.

Ni base alloys and their weld metals :

- Alloy 600: Ni15CrFe

- Alloy 690: Ni30CrFe

- Alloy 82 (weld metal) : Ni20CrFe

Primary water (PWR)

- $\mathrm{T}=275^{\circ} \mathrm{C}-345^{\circ} \mathrm{C}$

- $P=150$ bar

- Water with boron and lithium

- $\mathrm{pH}=7.2$

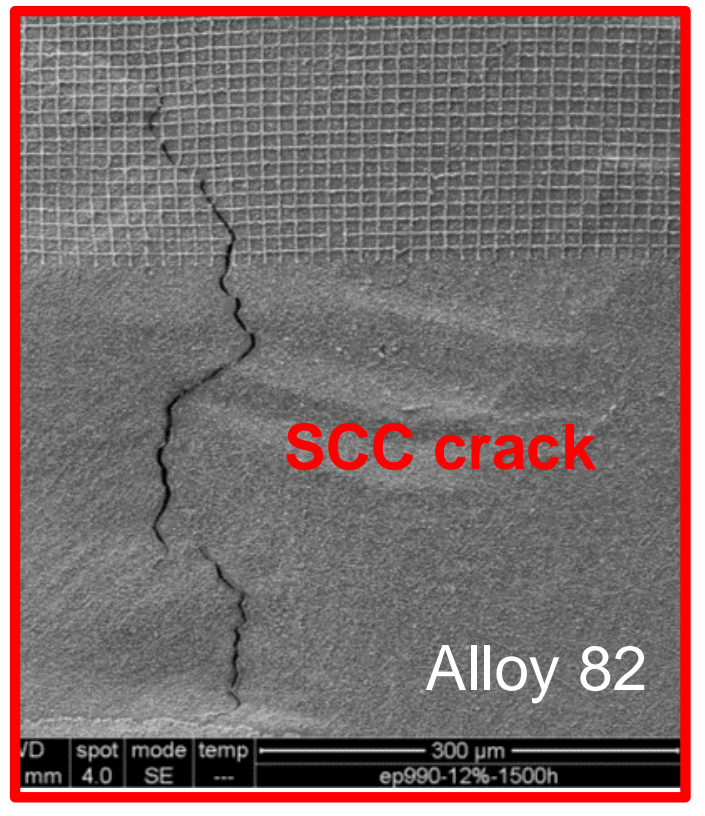

Applied strain or stress

Residual stresses 


\section{CONTEXT : SCC}

\section{MINDS}

\section{Stages of stress corrosion cracking}

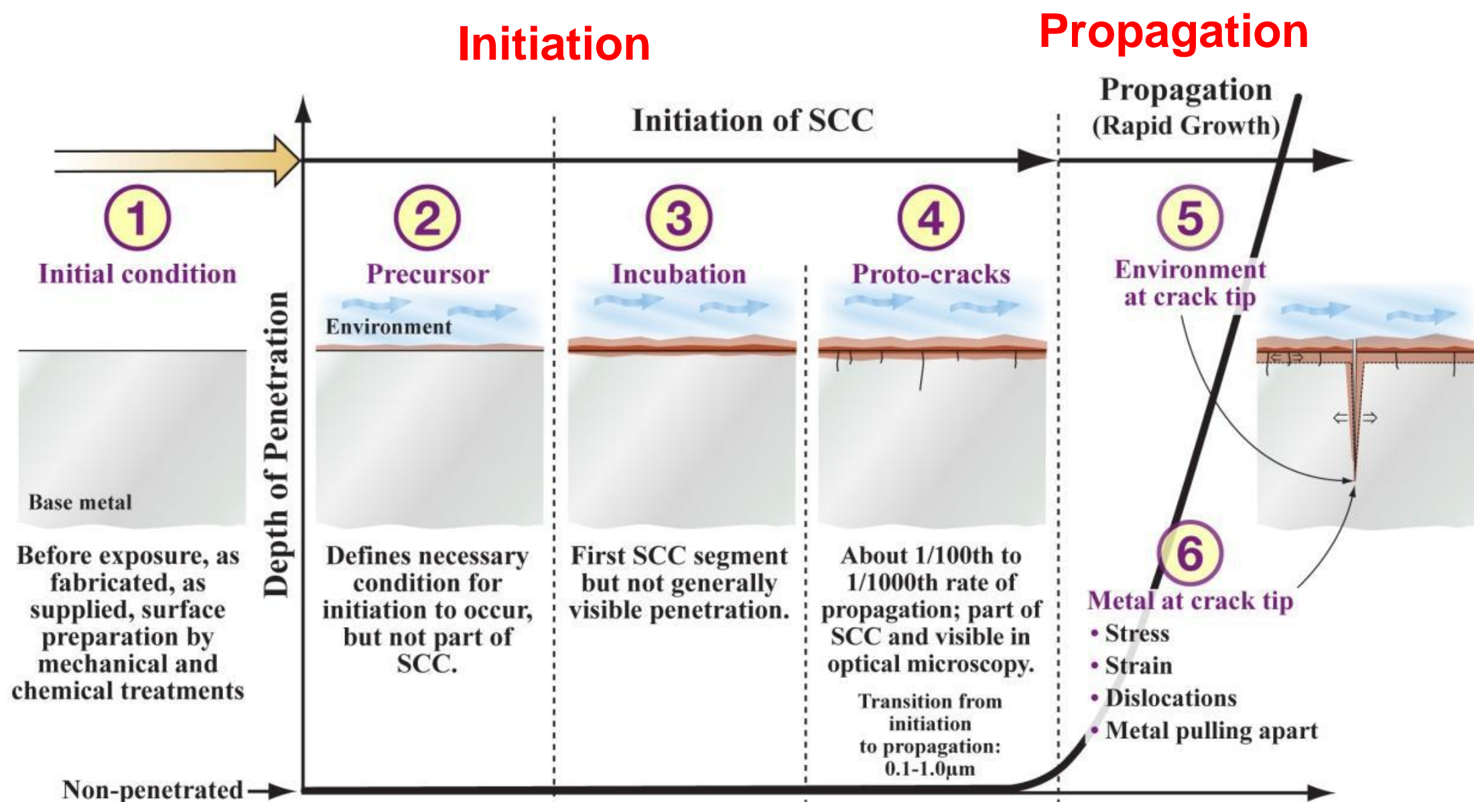

R.W. Staehle, "Quantitative Micro-Nano (QMN) Approach to SCC Mechanism and Prediction - Starting a Third Meeting," Presented at the 15th International Conference on Environmental Degradation of Materials in Nuclear Power Systems - Water Reactors, Colorado Springs, Colorado, August 7-11, 2011 


\section{CEA CONTEXT : SCC}

\section{$\because$ MINDS}

Two modes of propagation

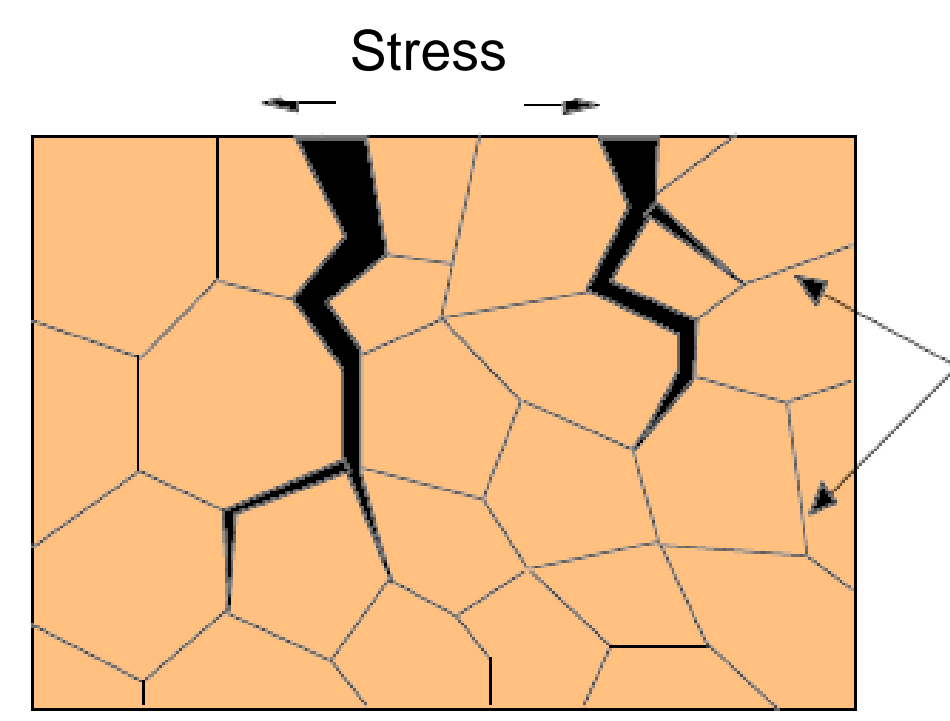

Intergranular cracks

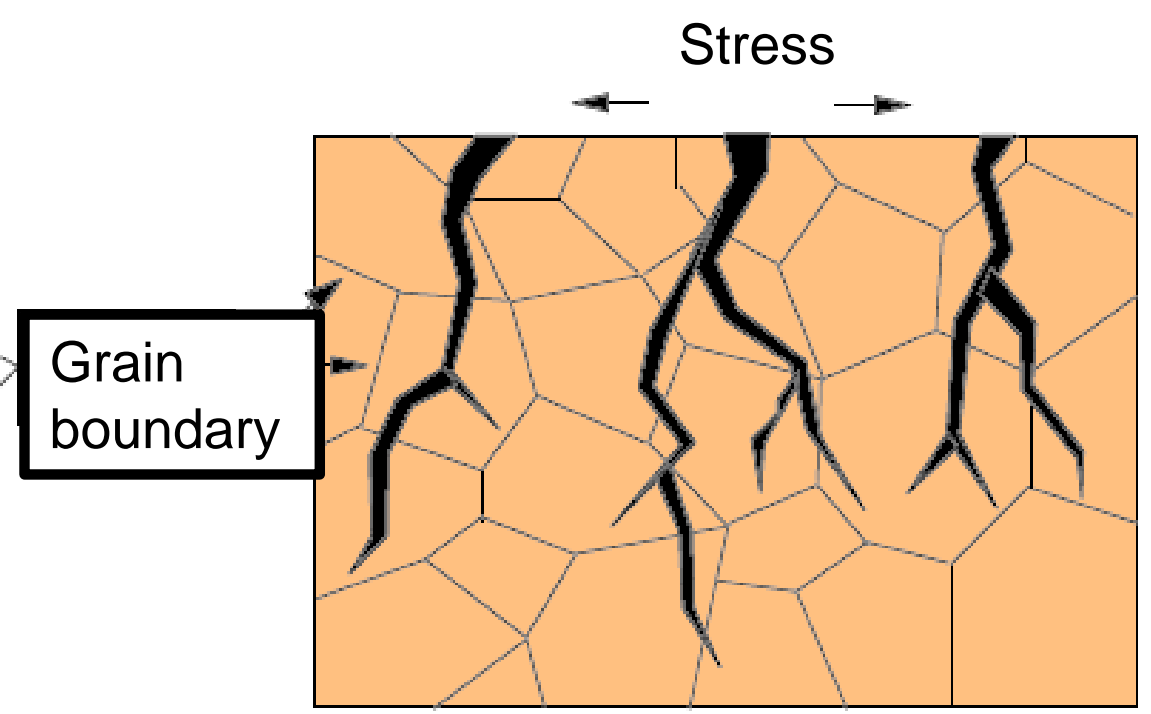

Transgranular cracks

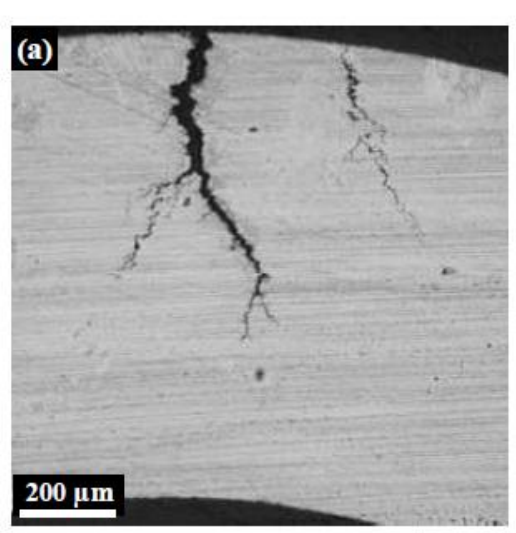

Alliage 600 , coulée NX2650 


\section{cea}

\section{$\because \mathrm{MINDS}$}

\section{SCC OF ALLOY 600 IN PWR PRIMARY WATER}




\section{SCC OF ALLOY 600 IN PWR PRIMARY WATER}

MINDS

\section{Context and objective}

- Many laboratory studies have been performed (for more than 30 years) and dealed with the influence of :

- Microstructural parameters : chemical composition, precipitation, carbon content, ...

- Environmental paremeters : temperature, hydrogen partial pressure, $\mathrm{pH}$...

- Mechanical parameters : tensile stress, strain path, ...

- But the assumed mechanism are still not well known...

- Need for a predictive model in the frame of life extension of PWRs...

- for Alloy 690, assumed not to be susceptible to SCC in nominal PWR primary water : to better understand the mechanism for Alloy 600 will help us to better predict the long term behaviour of Alloy 690

- for nickel base weld metals : more recent in-service cases and less laboratory studies 


\section{SCC OF ALLOY 600 IN PWR PRIMARY WATER}

\section{MINDS}

Characterization of the crack by high resolution TEM analysis :

- Cr-rich oxide at the tip.

- Chromium depletion (Ni enrichment) ahead of the crack tip and on one side of the crack (or IGA)

- Asymetric aspect of the SCC crack.
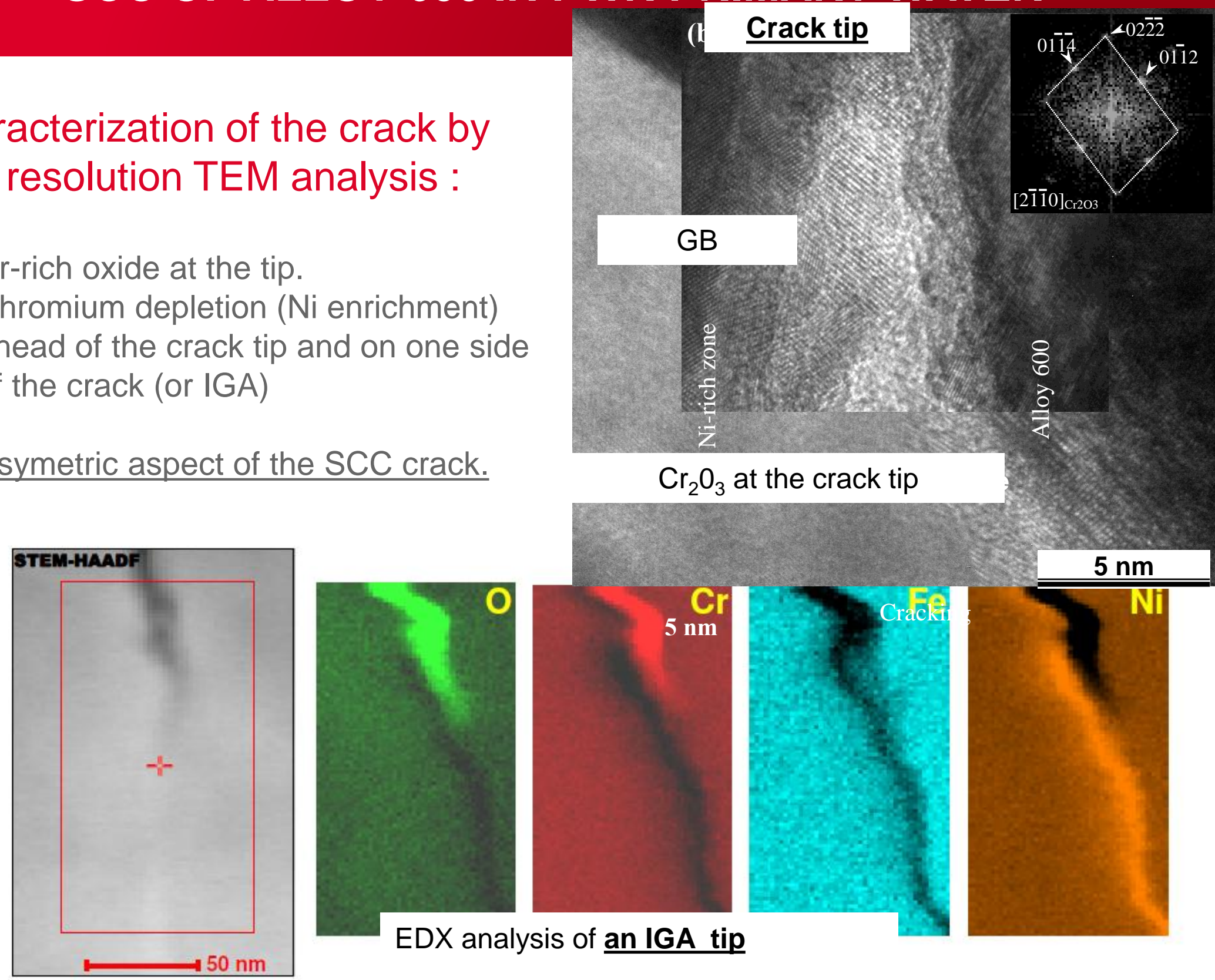


\section{SCC OF ALLOY 600 IN PWR PRIMARY WATER}

\section{MINDS}

\section{Characterization of the oxides in SCC cracks}

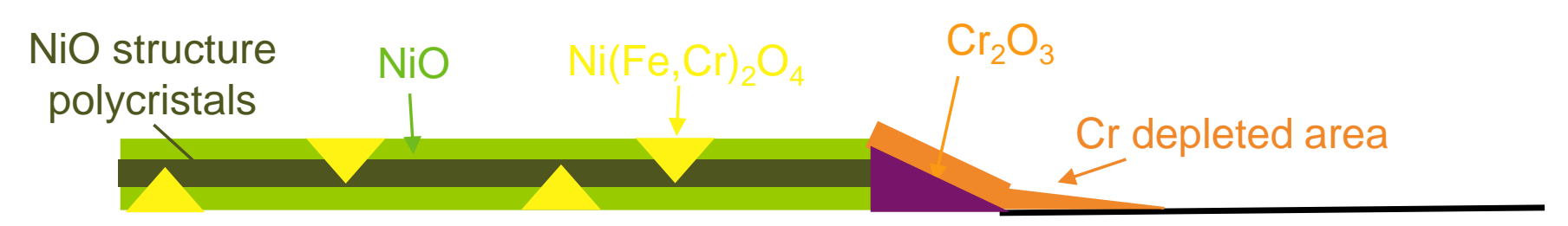

GB

$$
\frac{a\left(\mathrm{H}_{2} \mathrm{O}\right)}{a\left(\mathrm{H}_{2}\right)} \uparrow
$$

- According to thermodynamics calculations, it implies an increasing oxidizing power in the crack.

- Asymetric aspect of the Cr depletion (or Ni enrichment)

Advance TEM characterization of stress corrosion cracking of Alloy 600 in pressurized water reactor primary water environment, M. Sennour, P. Laghoutaris, C. Guerre, R. Molins, JNM 393 (2009) 254-266 


\section{SCC OF ALLOY 600 IN PWR PRIMARY WATER}

\section{MINDS}

Modelling of SCC of Alloy 600 ([Laghoutaris2009])

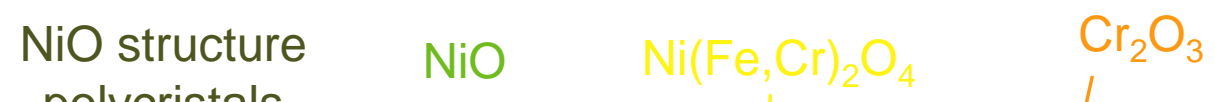
polycristals
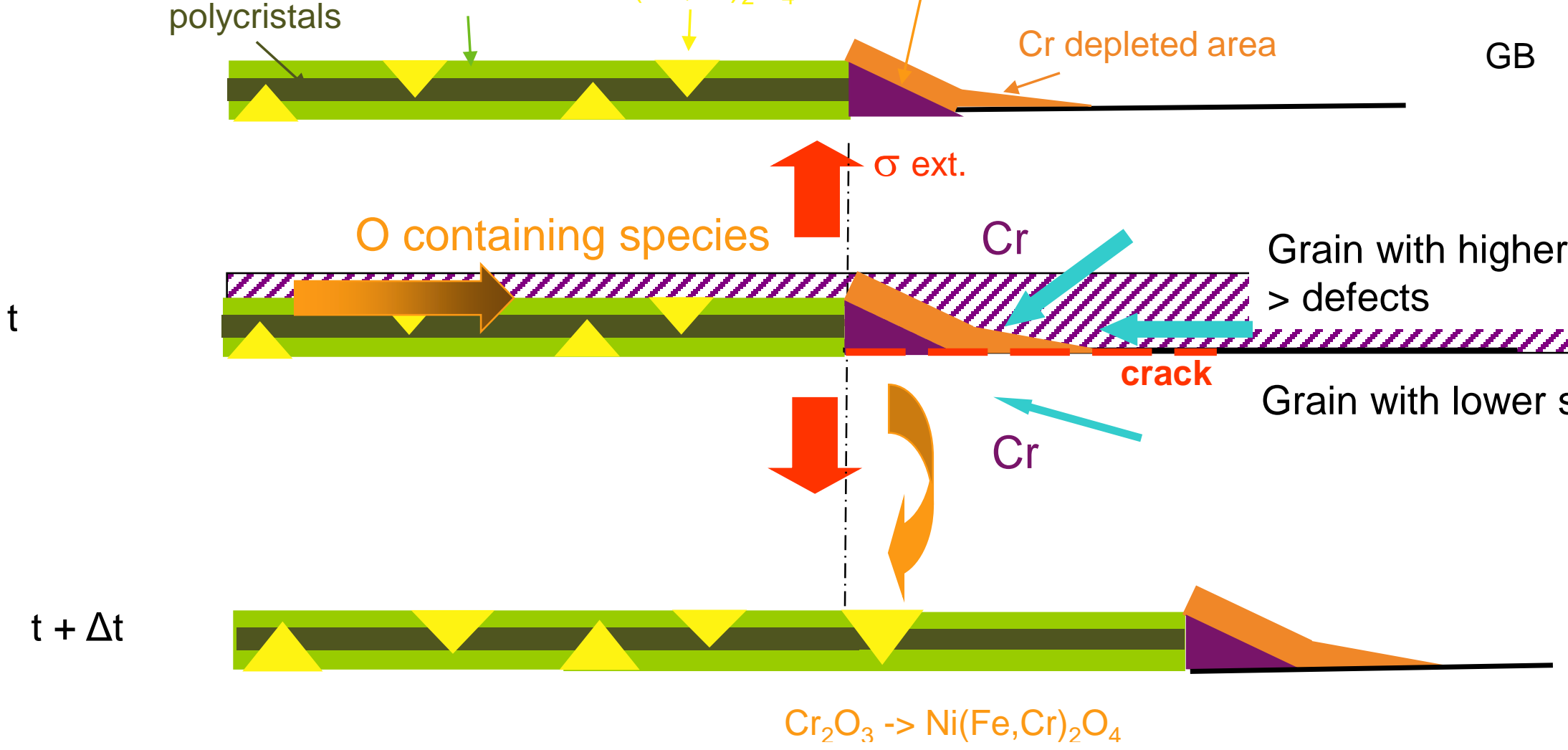

- This mechanism is based:

- on a selective oxidation of chromium,

- a asymetric aspect of the crack tip (oxidation and chromium depletion) controlled by the local defects density. 


\section{SCC OF ALLOY 600 IN PWR PRIMARY WATER}

\section{MIN口S}

\section{Model microstructure}

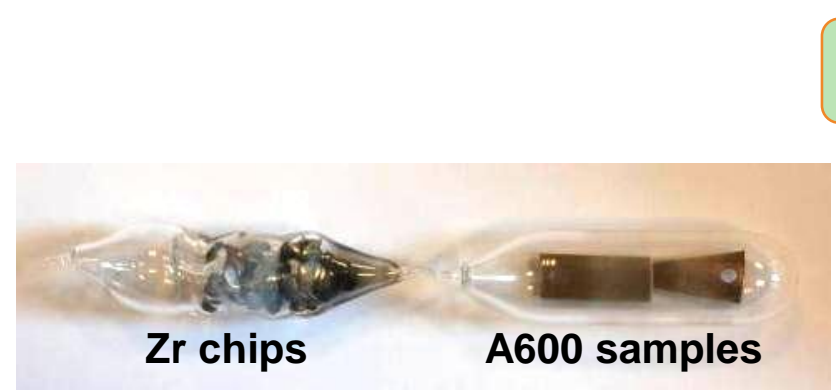

$1050^{\circ} \mathrm{C}-1 \mathrm{~h}$

water quenching

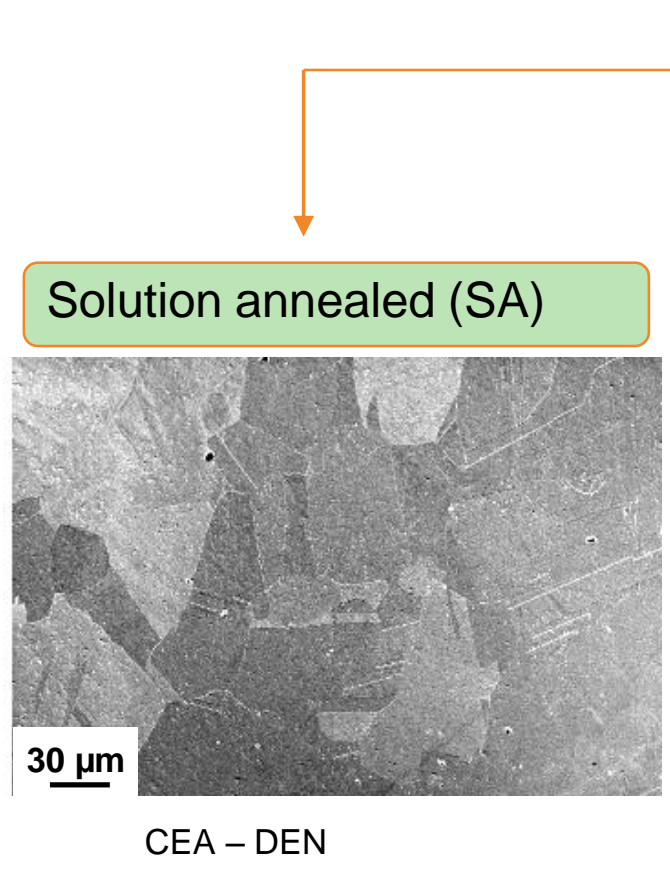

Alloy 600

$30 \mu \mathrm{m}$

Heat WF675 Susceptible to SCC

\section{STEM-DF}

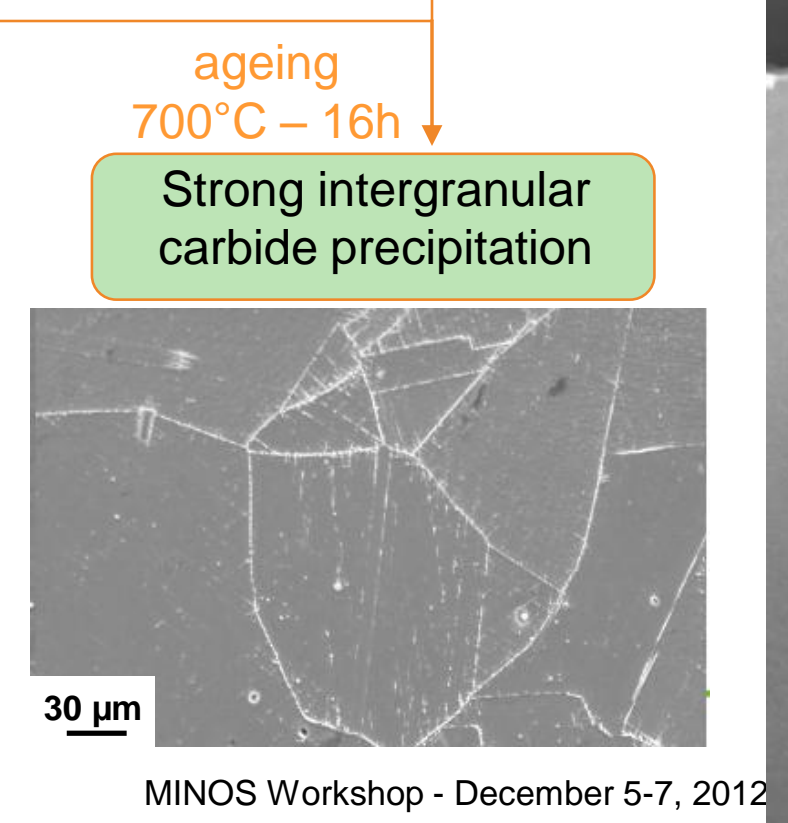




\section{SCC OF ALLOY 600 IN PWR PRIMARY WATER}

\section{¿MINDS Solution - annealed (no IG carbide)}

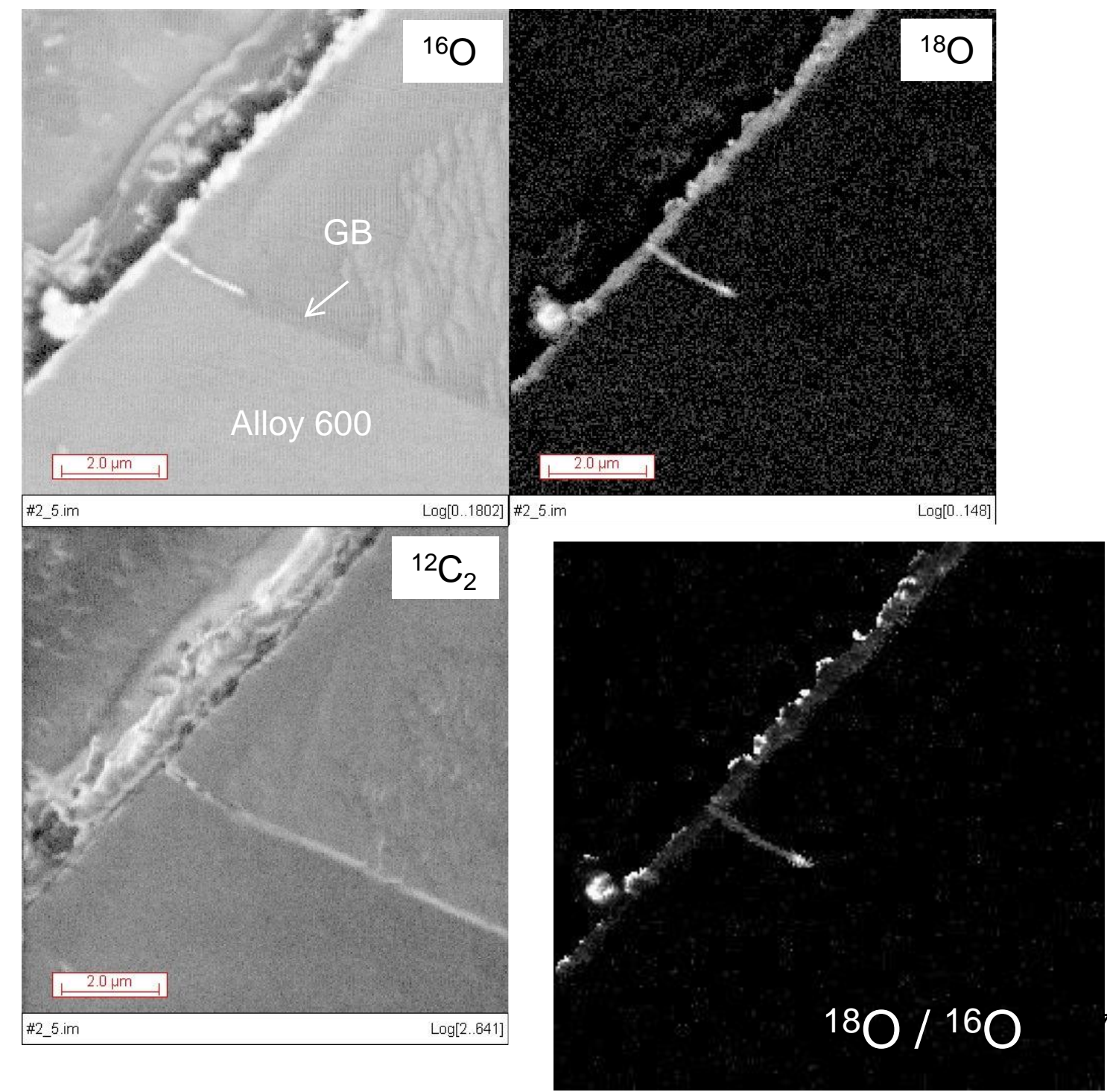

Nano-SIMS analysis on intergranular attack formed during exposure in water.

Conditions :

- $1340 \mathrm{hr}$ in nominal primary water at $325^{\circ} \mathrm{C}$

- $67 \mathrm{hr}$ in water containing tracers $\left({ }^{18} \mathrm{O}\right)$ at $325^{\circ} \mathrm{C}$

$\rightarrow{ }^{18} \mathrm{O}$ is located at the tip of the IG penetration and in the outer part of the oxide surface layer

$->{ }^{18} \mathrm{O}$ transport during $67 \mathrm{hr}$ up to the tip of the oxidized grain boundary

-> long and thin IGA

Nano-SIMS analysis were performed by Nathalie Vallé Public research centre Gabriel Lippmann, Material

2 analysis department 


\section{Cea SCC OF ALLOY 600 IN PWR PRIMARY WATER}

\section{MIN口S}

IG carbide precipitation

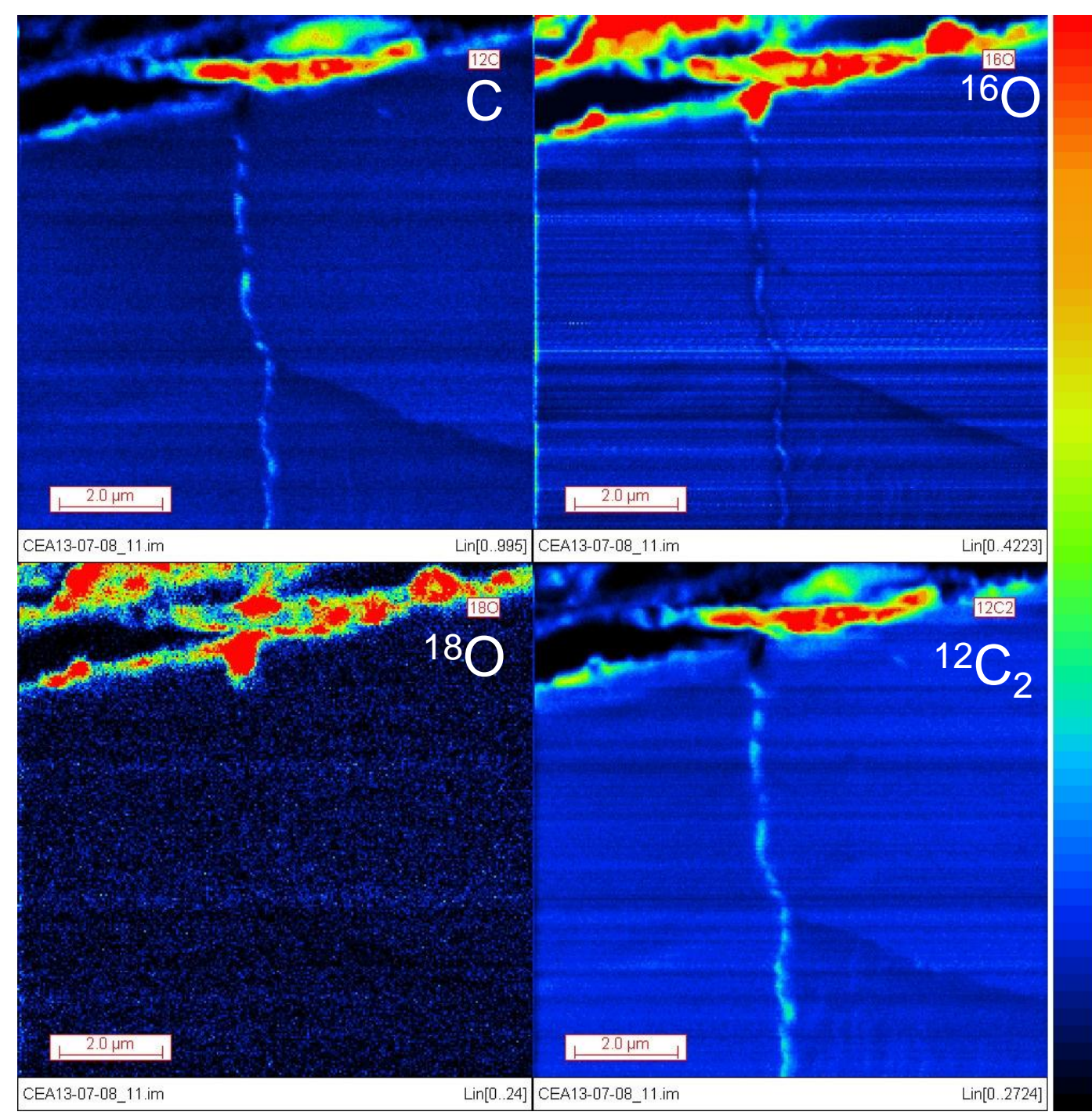

Nano-SIMS analysis

Conditions :

- $1340 \mathrm{hr}$ in nominal primary water at $325^{\circ} \mathrm{C}$

- $67 \mathrm{hr}$ in water containing tracers $\left({ }^{18} \mathrm{O}\right)$ at $325^{\circ} \mathrm{C}$

-> large and short IGA 


\section{SCC OF ALLOY 600 IN PWR PRIMARY WATER}

MINDS

\section{Conclusion and perspectives}

- Oxygen transport through the surface oxide layer and in the crack is not a ratecontrolling step.

- SCC cracks and intergranular attacks are asymetric (Alloy 600)

- Chromium depletion is observed on one side of the crack or of the IGA :

- in the grain containing more defects ?

- depending on the strain ?

- chromium diffusion is accelerated by strain ?

- Influence of intergranular carbides

- IGA is shorter and larger

- intergranular carbides could act as a barrier to the formation and growth of the intergranular attack (and therefore for crack initiation)

- slower oxidation kinetics of the carbides compared to the alloy?

- same effect with $\mathrm{Cr}_{7} \mathrm{C}_{3}$ and $\mathrm{Cr}_{23} \mathrm{C}_{6}$ ([Payne and Mc Intyre 87]? 


\section{cea}

\section{$\because \mathrm{MINDS}$}

\section{SCC OF ALLOY 82 IN PWR PRIMARY WATER}




\section{SCC OF ALLOY 82 IN PWR PRIMARY WATER}

\section{MIN口S}

\section{Alloy 82 butt welds}

- Alloy 82 is a weld metal deposited by arc welding (GTAW or FCAW)

filler metal : Alloy 82
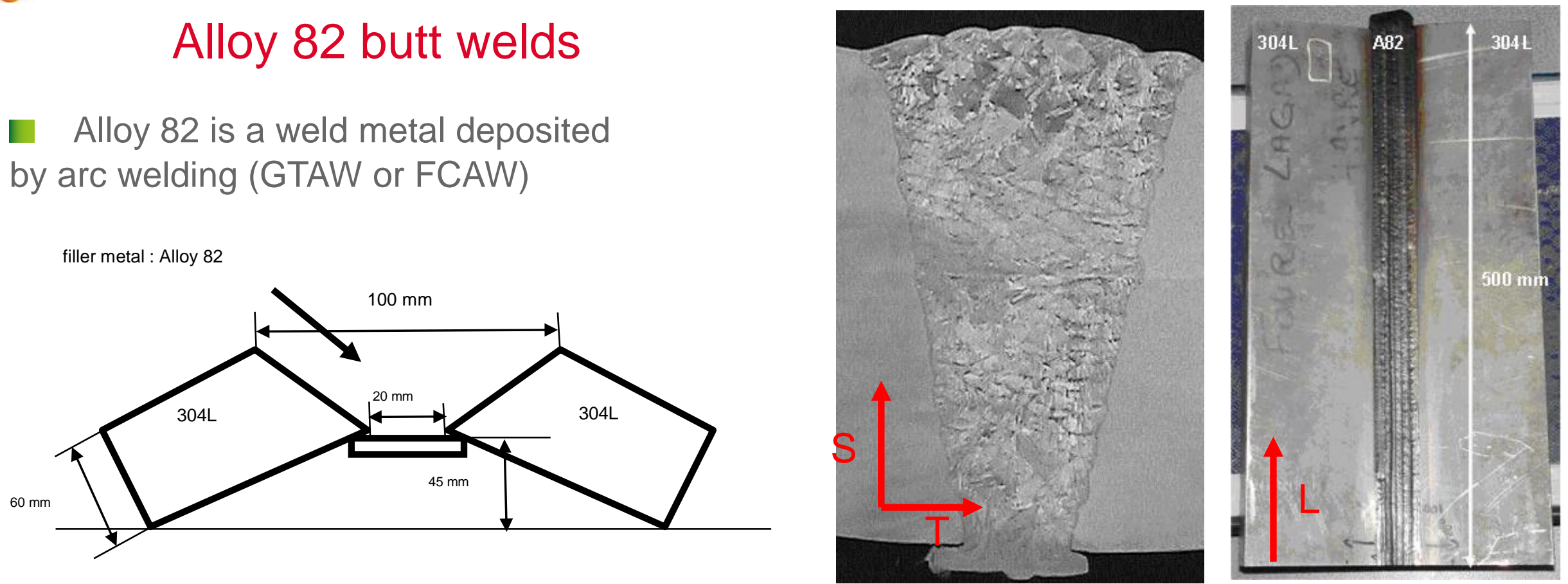

Two metallurgical states : as - welded or heat - treated $\left(7 \mathrm{hr}\right.$ at $\left.600^{\circ} \mathrm{C}\right)$

- Chemical composition

\begin{tabular}{|l|l|l|l|l|l|l|l|l|l|l|l|l|} 
Weight \% & $\mathrm{C}$ & $\mathrm{S}$ & $\mathrm{Si}$ & $\mathrm{Mn}$ & $\mathrm{Ni}$ & $\mathrm{Fe}$ & $\mathrm{Cu}$ & $\mathrm{Cr}$ & $\mathrm{Nb}$ & $\mathrm{Ti}$ & $\mathrm{P}$ & $\mathrm{Co}$ \\
\hline RCC-M & $<0.1$ & $<0.015$ & $<0.5$ & $2.5 / 3$. & $>67$ & $<3$ & $<0.5$ & $18 / 22$ & $2 / 3$ & $<0.75$ & $<0.03$ & $<0.1$ \\
\hline
\end{tabular}




\section{Cea SCC OF ALLOY 82 IN PWR PRIMARY WATER}

\section{MIN口S}

\section{Microstructure}

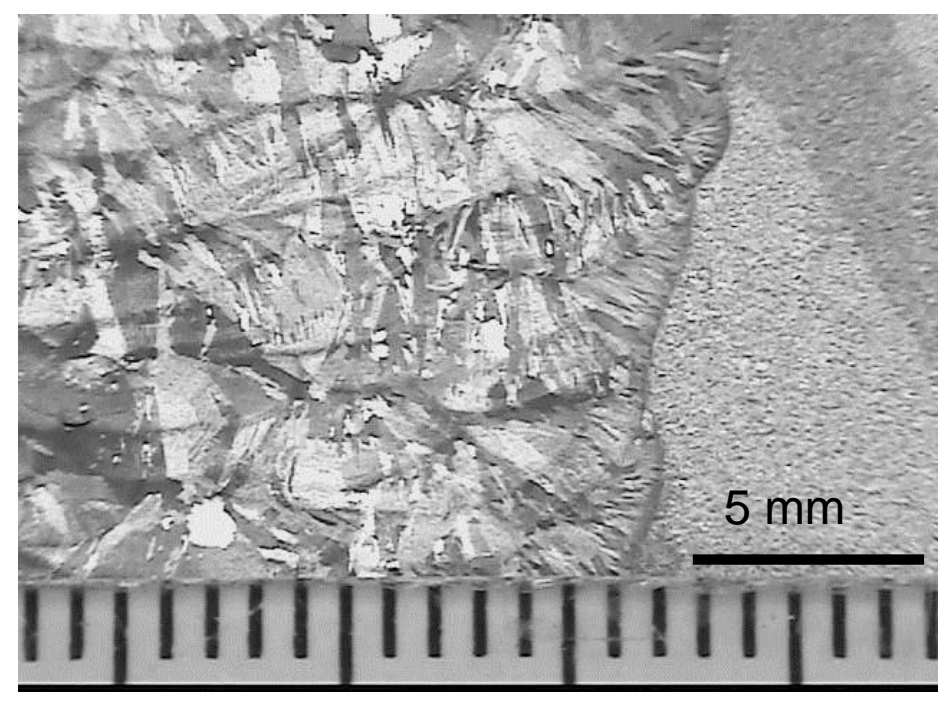

$50 \mu \mathrm{m}$

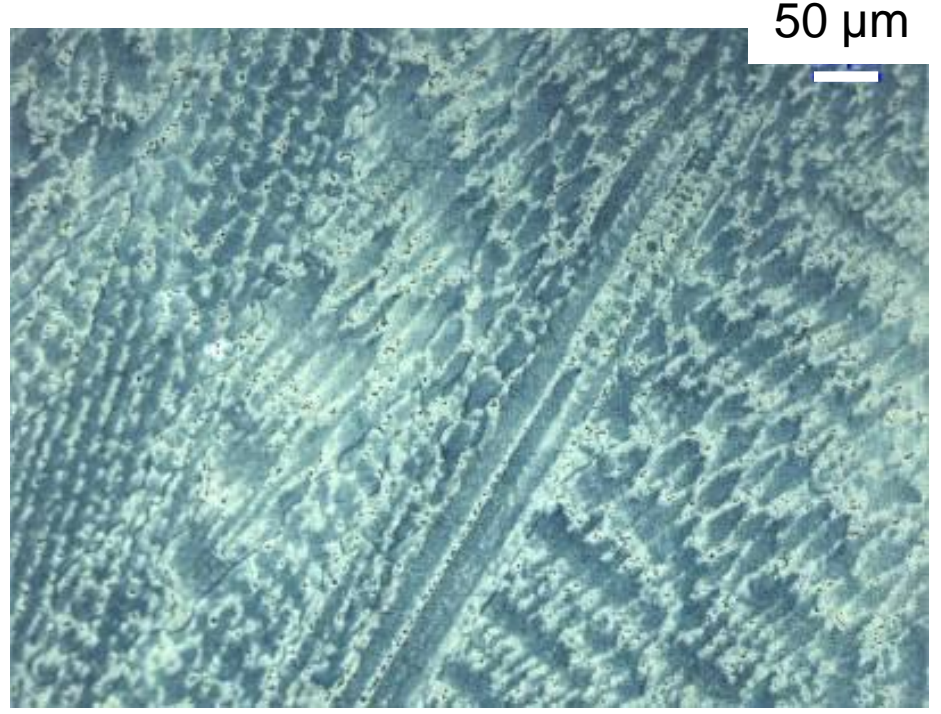

- Columnar grains made of several slightly disoriented dendrites.

- One grain can cross several weld passes. 


\section{SCC OF ALLOY 82 IN PWR PRIMARY WATER}

\section{MIN口S}

\section{Microstructure (EBSD)}

Dendrites growth direction

(S)
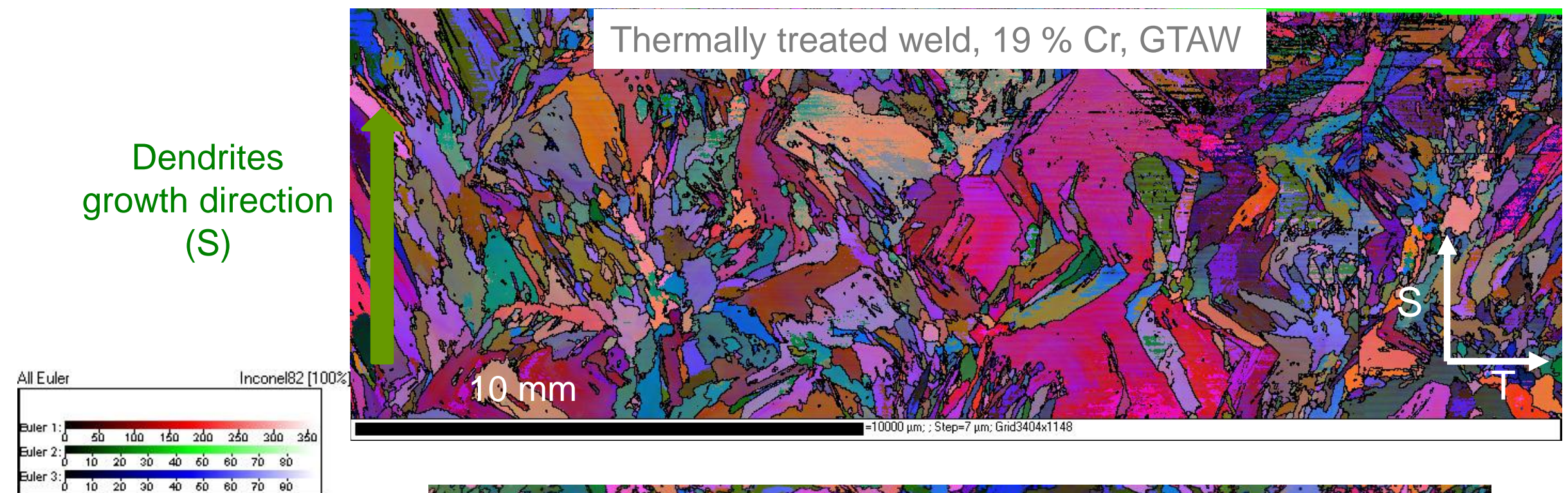

Welding direction (L)

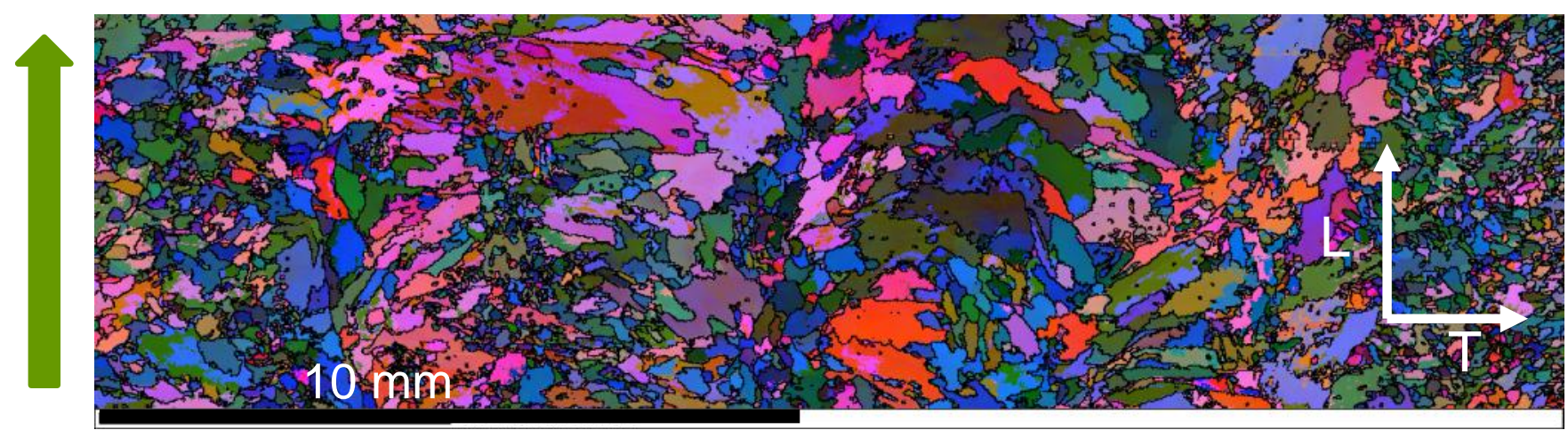

- More or less elongated grains along the dendrite growth direction, heterogeneous grain size. - The Representative Elementary Volume (REV) is centimetric. 


\section{SCC OF ALLOY 82 IN PWR PRIMARY WATER}

\section{MIN口}

\section{Crack propagation test}

- CT specimen fracture surface analysis
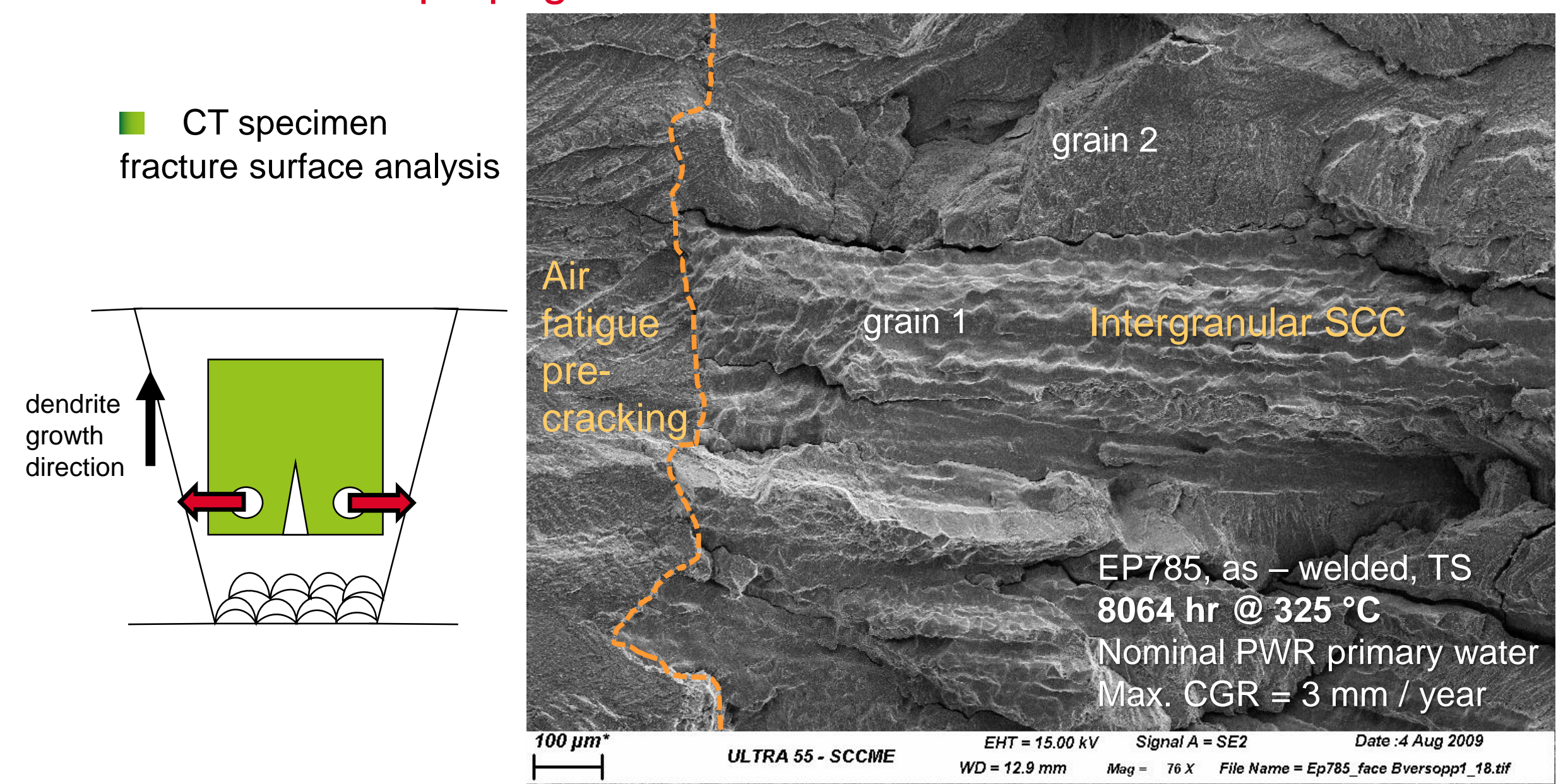

- Intergranular crack path.

- Isolated initiation sites along the crack front and crack branching : induced by the microstructure 


\section{SCC OF ALLOY 82 IN PWR PRIMARY WATER}

\section{¿MINDS Crack propagation test}

E Maximum Crack Growth Rate : $4 \mathrm{~mm} / \mathrm{year}$-> CGR can be very high along susceptible grain boundaries.

Whereas others grain boundaries can remain unaffected (even if they are highly stress during several thousands hours)

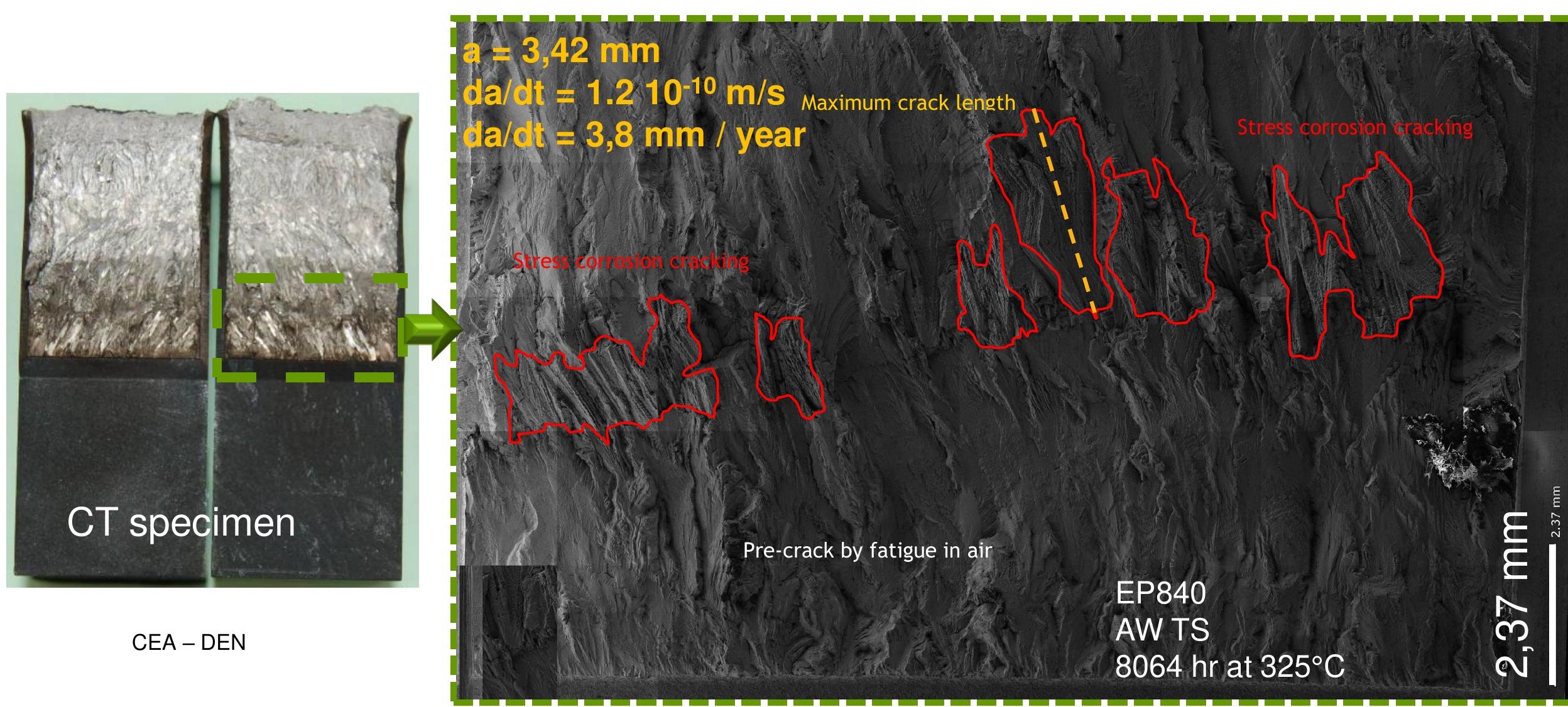




\section{SCC OF ALLOY 82 IN PWR PRIMARY WATER}

\section{MINDS}

\section{Influence of the thermal treatment on CGR}

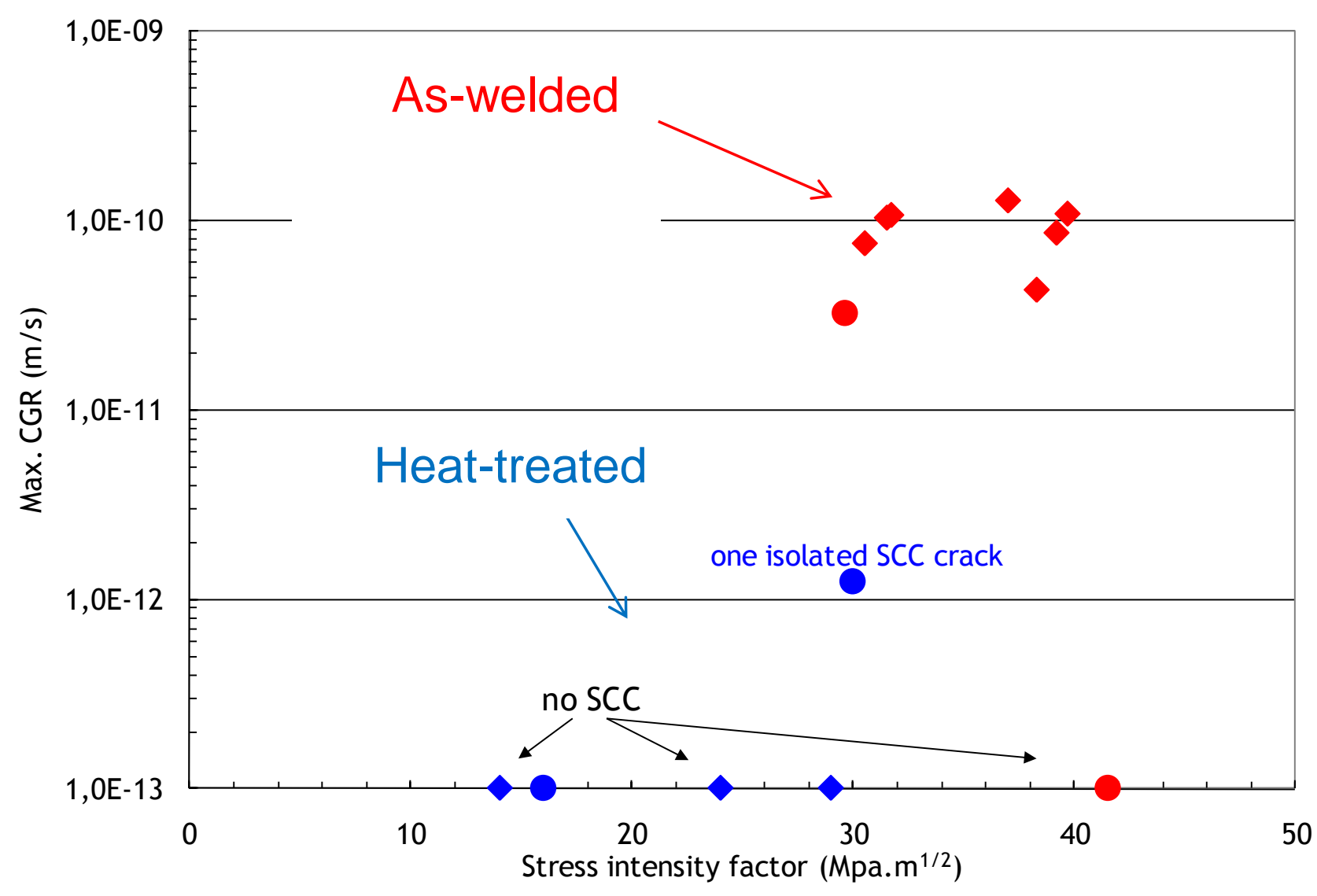

Number of cracked specimen :

As-welded :

10 out of 11

Heat treated :

$1^{*}$ out of 7

(*one isolated crack)

- The thermal treatment reduces the susceptibility to SCC crack propagation for Alloy 82.

- This thermal treatment was designed to stress relieved components which are welded (and not designed for the weld). All Alloy 82 welds are thermally treated in France. 


\section{SCC OF ALLOY 82 IN PWR PRIMARY WATER}

\section{Influence of the thermal treatment}

TEM observations of the GB (thermally treated weld)

- $\mathrm{NbC}$

- $\mathrm{Cr}_{23} \mathrm{C}_{6}$

$\left(\mathrm{Cr}_{23} \mathrm{C}_{6}\right.$ were not observed for as-welded weld)

- The thermal treatment induces the formation of $\mathrm{Cr}_{23} \mathrm{C}_{6}$.
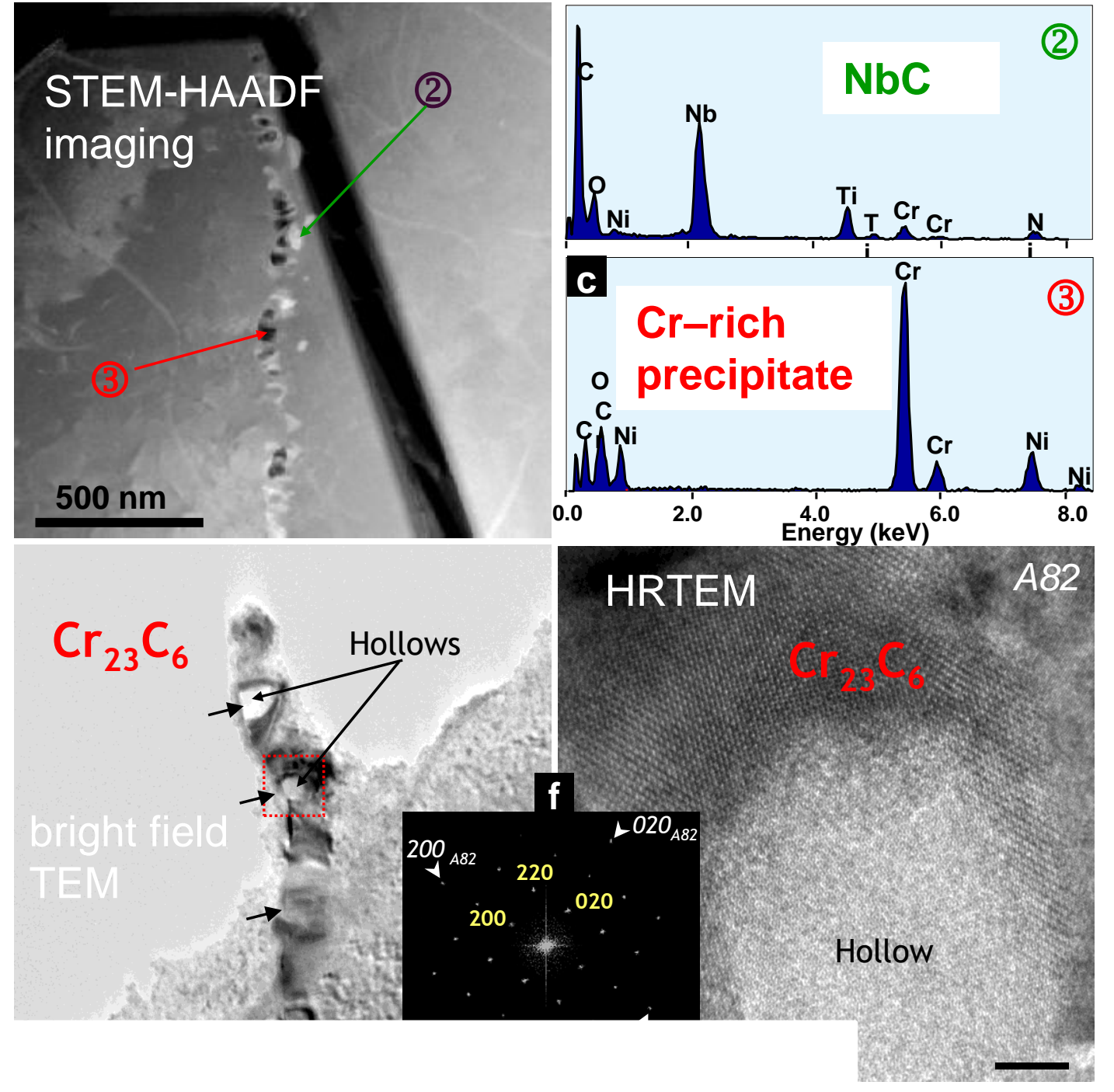


\section{Cea SCC OF ALLOY 82 IN PWR PRIMARY WATER}

\section{MIN口S}

Influence of the microstructure on the SCC inititation test

- U-bend specimen
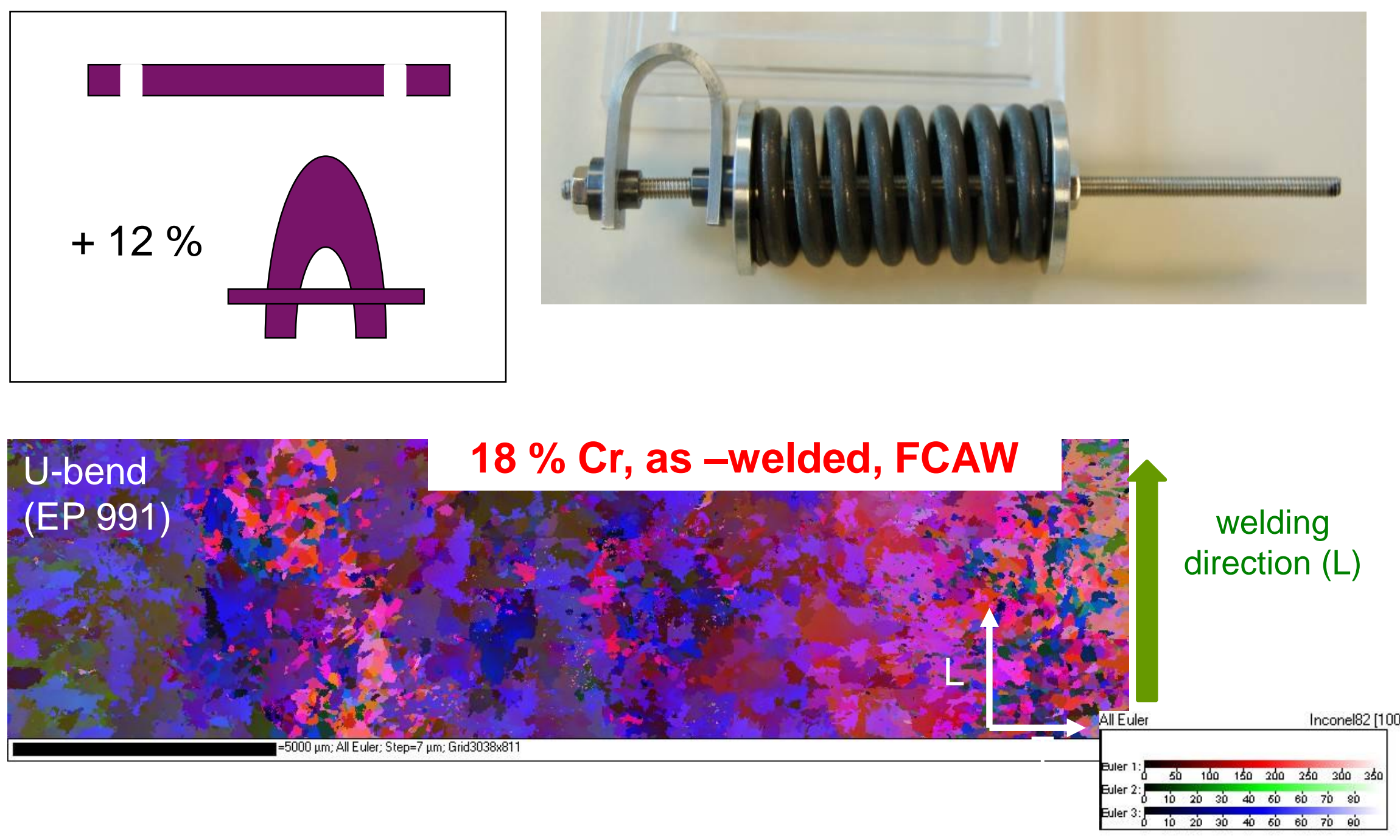


\section{SCC OF ALLOY 82 IN PWR PRIMARY WATER}

\section{$\because \mathrm{MINDS}$}

\section{$18 \% \mathrm{Cr}$, as -welded, FCAW}
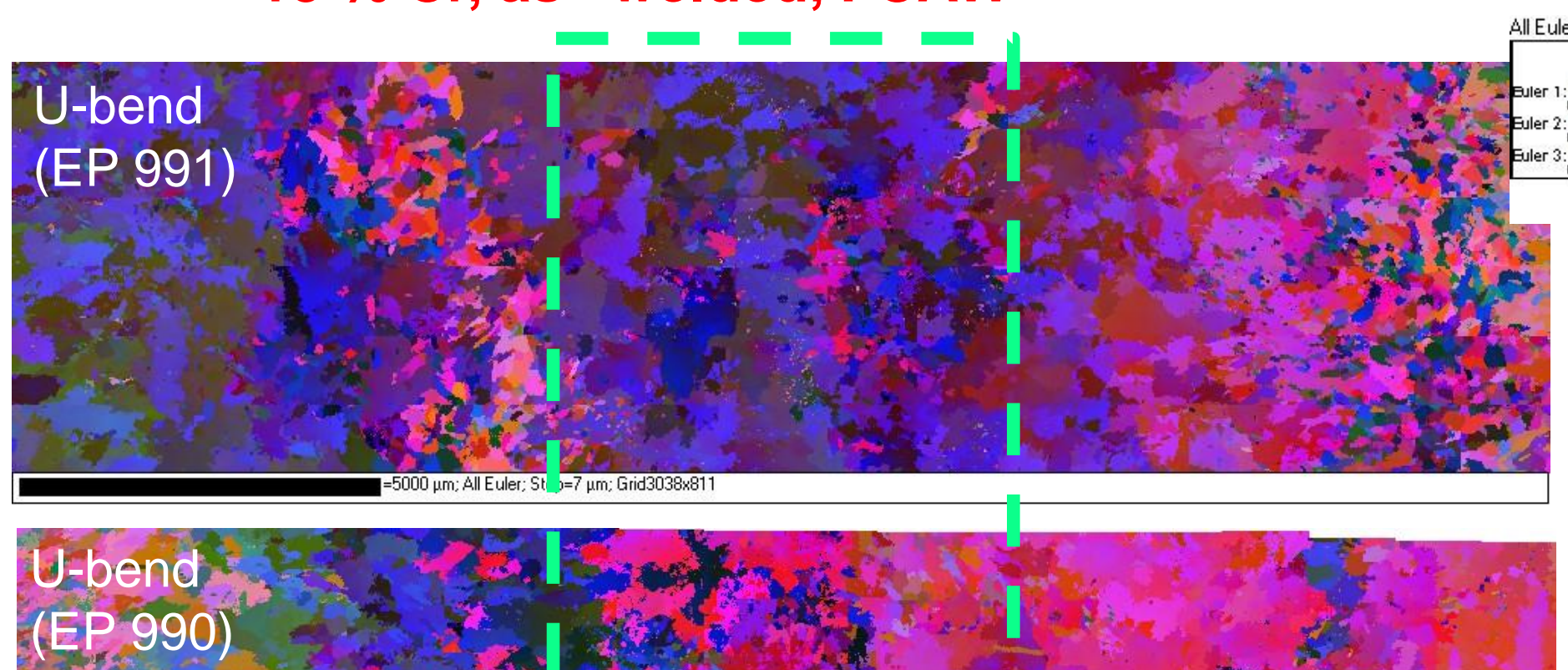

$=5000 \mu \mathrm{m}$; All Euler; St $\jmath=7 \mu \mathrm{m}$; Grid3038*811

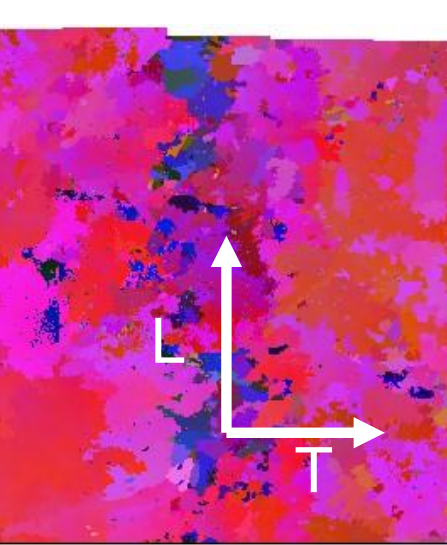

- Surfaces of two U-bend specimens (before straining) : not the same microstructure (end therefore grains and grain boundaries at the apex) it demonstrates the importance to fully characterize the specimens before the SCC tests. 


\section{Cea SCC OF ALLOY 82 IN PWR PRIMARY WATER}

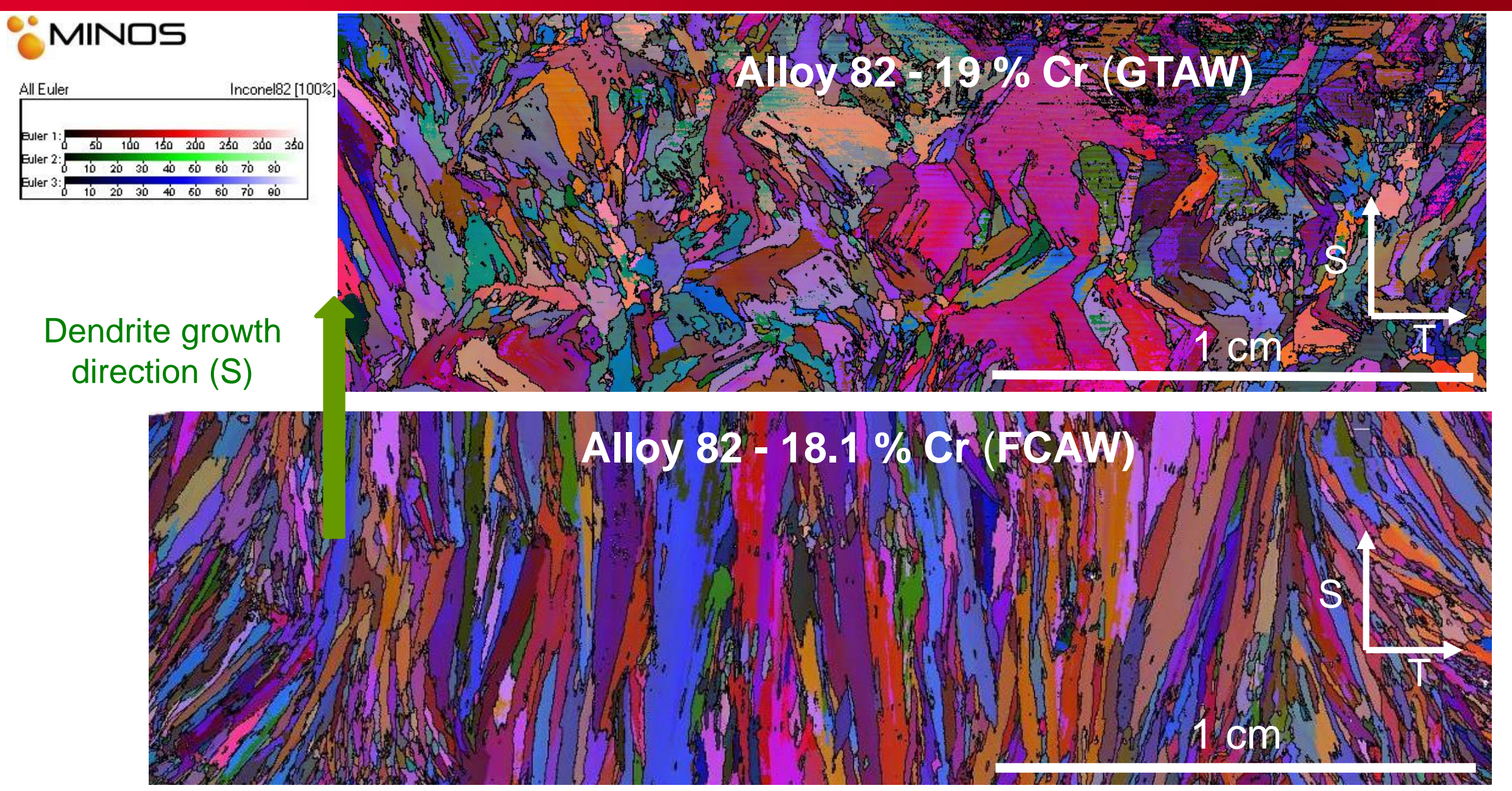

- Grains are much more elongated and orientated along the dendrite growth direction for the low Cr Alloy (18\% Cr).

-> the welding procedure (welding parameters) must also be taken into consideration. 


\section{SCC OF ALLOY 82 IN PWR PRIMARY WATER}

\section{MINDS}

Approach and purpose for crack initiation study (for weld metals)

The objective is to identify the microstructural features that enable SCC initiation in Alloy 82.

Microstructure (EBSD, SEM, ...)

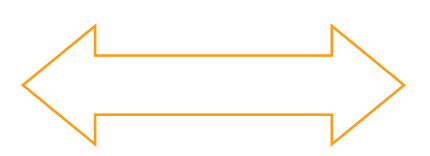

Local mechanical behaviour (local strain field, strain localization, etc...)

Stress corrosion cracking

(Initiation test)

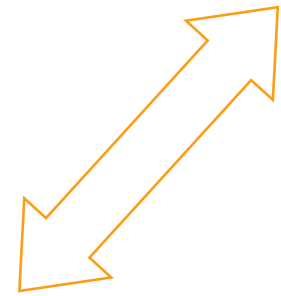

Deformation equivalente de Von Mises
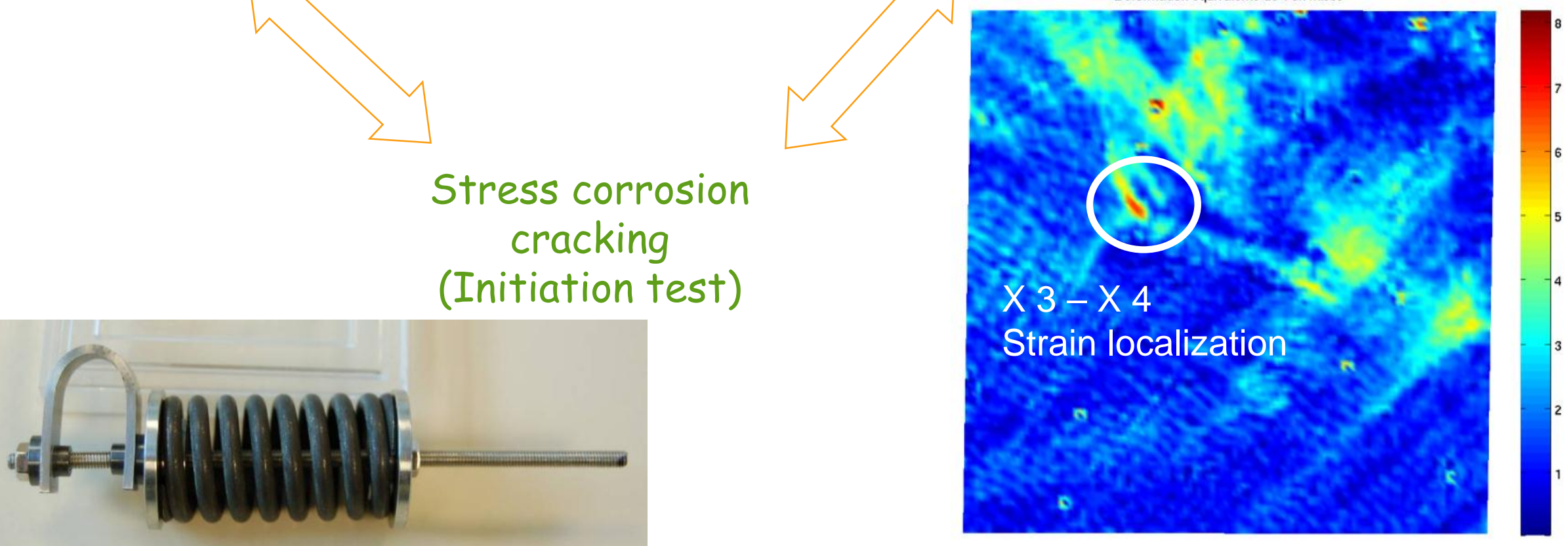


\section{CONCLUSION}

MINDS

- Stress corrosion cracking of nickel base alloys and of stainless steels is still a major in PWR in the frame of life extension.

- New approaches

- New experimental tools (nano-SIMS, HRTEM, FEG-SEM and EBSD, ...)

- In order to improve our knowledge of mechanism

- To get predictive models that could be applied to susceptible materials but also to assess the susceptibility of others materials (Alloy 690 , Alloy $52, \ldots$ )

- In order to take into account specific microstructure (texture) or anisotropic materials

- weld metals with centimetric representative elementary volume - REV

- anisotropic cold-worked materials

$-\ldots$. 


\section{REFERENCE}

\section{MINDS}

- SCC of Alloy 600

- M. Sennour, P. Laghoutaris, C. Guerre, R. Molins, Advanced TEM characterization of stress corrosion cracking of Alloy 600 in pressurized water reactor primary water environment, Journal of Nuclear Materials 393 (2009) 254-266

- P. Laghoutaris, J. Chêne, C. Guerre, O. Raquet, M. Sennour, R. Molins, F. Vaillant, P. Scott, Contribution to understanding Stress Corrosion Cracking of Alloy 600 in PWR Primary Water, in : Eurocorr 2007, Freiburg im Breisgau, Allemagne, 2007

- P. Laghoutaris, C. Guerre, J. Chêne, C. Duhamel, R. Molins, Contribution to a model for stress corrosion cracking of Alloy 600 in PWR primary water, in : Eurocorr 2009, Nice, France, 2009

- C. Guerre, P. Laghoutaris, J. Chêne, L. Marchetti, R. Molins, C. Duhamel, M. Sennour, Stress corrosion cracking of Alloy 600 in PWR primary water : influence of chromium, hydrogen and oxygen diffusion, 15th International Conference on Environmental Degradation of Materials in Nuclear Power Systems-Water Reactors, Colorado Springs, Colorado, August 7 - 11, 2011

- P. Laghoutaris, C. Guerre, J. Chene, R. Molins, F. Vaillant, I. De Curieres, Contribution to model stress corrosion cracking of Alloy 600 in PWR primary water, Workshop on Detection, Avoidance, Mechanisms, Modeling, and Prediction of SCC Initiation in Water-Cooled Nuclear Reactor Plants, 07/09/2008 12/09/2008, Beaune, France

\section{- SCC of Alloy 82}

- C. Guerre, C. Duhamel, M. Sennour, J. Crépin, M. Le Calvar, SCC crak growth rate of Alloy 82 in PWR primary water conditions - effect of a thermal treatment, 15th International Conference on Environmental Degradation of Materials in Nuclear Power Systems-Water Reactors, Colorado Springs, Colorado, August $7-11,2011$ 